\title{
PERAN INSTITUSI MASJID SEBAGAI PUSAT PEMBERDAYAAN \\ SOSIAL EKONOMI MASYARAKAT \\ (Studi di Masjid Sabilillah Malang)
}

\author{
Nur Faizaturrodhiah \\ M. Pudjihardjo \\ Asfi Manzilati \\ Fakultas Ekonomi dan Bisnis, Universitas Brawijaya Malang \\ Email:vayzavay@gmail.com
}

\begin{abstract}
This study aims to analyze the role of mosque institution as the center of socio-economic empowerment of the community. The study was conducted at Sabilillah Mosque which is a large national pilot mosque. The approach used is case study. The results of social empowerment research are, improving the quality of education, family assistance, business training, health services, network strengthening with mushollah. While economic empowerment among others economic empowerment through mosque cooperative, economic empowerment dhuafa through business capital and provision of production facilities, economic empowerment through provision of market pujasera. To generate other funding sources as a means to empower the community, Sabilillah Mosque organizes auditorium, cash receipts, and minimarket management cooperation.
\end{abstract}

Keywords: Mosque, Social Economic Empowerment, welfare.

\section{PENDAHULUAN}

Problematika masyarakat miskin masih banyak dijumpai di Kota Malang, seperti rendahnya pendapatan masyarakat, ketidakmampuan mengakses pendidikan kejenjang lebih tinggi, dan sulitnya mendapatkan pelayanan kesehatan, serta belum tercukupinya kebutuhan sehari-hari.

Masjid Sabilillah sebagai lembaga keagamaan di Kota Malang, berupaya hadir untuk menjadi fasilitator bagi masyarakat, melalui program pemberdayaan.

Konsep pemberdayaan merupakan paradigma baru dalam pembangunan masyarakat yang melibatkan masyarakat dalam kegiatan pembangunan, baik dalam perencanaan, pelaksanaan, maupun evaluasi.

Pemberdayaan dilakukan sebagai proses mengembangkan, memandirikan, menswadayakan, memperkuat posisi tawar menawar masyarakat lapisan bawah terhadap kekuatan-kekuatan penekan di segala bidang dan sektor kehidupan (Sutoro, 2002). 
Berbagai program yang dirancang dan dilaksanakan bertujuan untuk merubah atau melakukan pembaharuan pada suatu komunitas atau masyarakat dari kondisi ketidakberdayaan menjadi berdaya dengan menitikberatkan pada pembinaan potensi dan kemandirian masyarakat. Salah satu prinsip dalam pemberdayaan adalah penguasaan terhadap kemampuan sosial ekonomi yaitu, bagaimana masyarakat lemah memperoleh akses informasi, akses pengetahuan dan ketrampilan, akses untuk berpartisipasi dalam organisasi sosial, dan akses ke sumber-sumber keuangan, kemampuan memanfaatkan dan mengelola mekanisme produksi, distribusi dan jasa. Kemampuan dalam konteks ini menyangkut kinerja individu yang merupakan wujud kompetensi individu tersebut dapat meningkat melalui proses pembelajaran maupun terlibat langsung di lapangan.

Di Masjid Sabilillah kompetensi pengelolaan ekonomi, baik dari LAZIS maupun Koperasi Masjid Sabilillah dijalankan melalui pendampingan dan bina usaha. LAZIS terkonsentrasi khusus untuk kaum dhuafa dan juga fakir miskin yang ingin berwirausaha dan juga yang telah memiliki usaha dan ingin mengembangkan usahanya. Sehingga LAZIS Sabilillah menjembatani dan memberikan akses kepada masyarakat. Tidak hanya dalam bentuk uang, namun juga dalam bentuk sarana prasarana pendukung serta berbagai pembinaan serta motivasi dan pengetahuanpun diberikan untuk keluarga binaan yang terdiri dari kaum dhuafa. Adapun untuk program bina usaha, LAZIS Sabilillah mengeluarkan dana dari zakat infak dan juga shadaqah (ZIS) sebesar Rp. 92.328.500.

Sedangkan di Koperasi Masjid Sabilillah (KOPMAS), anggota diberikan kemudahan untuk mengakses dana pinjaman, yaitu kelonggaran persyaratan dalam mengakses modal dipermudah dengan jaminan yang ringan, yakni seperti Kartu Keluarga (KK), surat nikah dan akta kelahiran anak. Kemudahan lainnya yang dapat diterima anggota ialah seperti tidak adanya denda yang dikenakan kepada anggota yang terlambat mengembalikan pinjaman. Hal ini menjadikan anggota Koperasi Sabilillah terus meningkat. Hingga tahun 2016 tercatat sebanyak 954 anggota. Mayoritas anggota koperasi Masjid Sabilillah terdiri dari pedagang kaki lima, tukang parkir, penjahit, guru dan karyawan Masjid Sabilillah.

Tulisan ini dibuat dan dimaksudkan sebagai pemetaan atas berbagai konsep dasar pemberdayaan masyarakat. Selain itu, tulisan ini mencoba menganalisis sejauh mana relevansinya dengan peranan masjid dalam 
mewujudkan kesejahteraan sosial ekonomi masyarakat. Dengan harapan pemahaman akan memfungsikan masjid sebagai upaya mengaktualisasikan serta mengembangkan nilai sosial ekonomi.

\section{KAJIAN PUSTAKA}

\section{Pemberdayaan Sosial Ekonomi}

Pemberdayaan (empoworment) berasal dari kata power, yang berarti kekuasaan atau keberdayaan. Sedangkan istilah pemberdayaan merupakan terjemah dari istilah asing yaitu empowerment. Secara sederhana maka pemberdayaan berarti penguatan.

Konsep pemberdayaan menjadi sangat penting terutama karena memberikan sudut pandang yang positif terhadap orang miskin. Orang miskin tidak dilihat sebagai orang yang serba kekurangan (misalnya, kurang makan, kurang pendapatan, kurang sehat, kurang dinamis) dan objek pasif penerima pelayanan belaka. Melainkan sebagai orang yang memiliki beragam kemampuan yang dapat dimobilisasi untuk perbaikan hidupnya. Konsep pemberdayaan memberi kerangka acuan mengenai matra kekuasaan (power) dan kemampuan (kapabilitas) yang melingkup aras sosial, ekonomi, budaya, politik dan kelembagaan (Chaidir, 2009).

Pemberdayaan sosial ekonomi masyarakat, menyangkut suatu proses yang dijalankan untuk meningkatkan kemampuan sumber daya manusia (SDM) dan menyadarkan posisi dan peran seseorang dalam kaitannya dengan kehidupan sosial dalam komunitasnya. Adapun sasarannya diutamakan kepada masyarakat kelas bawah untuk mampu beraktifitas dalam bidang ekonomi dan memiliki penghasilan yang lebih baik, sehingga mampu menanggung dampak negatif dari pertumbuhan yang terjadi.

Dalam proses dan tahapan pemberdayaan diperlukan tenaga pendamping untuk pelaksanaan tugas serta memiliki posisi penting dan strategis dalam menentukan kinerja program. Adi (2003) menjelaskan tahapan yang dilakukan tenaga pendamping dalam proses pemberdayaan masyarakat sebagai berikut :

1).Tahap Persiapan. 2).Tahap Pengkajian. 3).Tahap Perencanaan Alternatif Program atau Kegiatan dan Tahap Pemformulasian Rencana Aksi. 4).Tahap capacity building dan networking. 5).Tahap pelaksanaan dan pendampingan. 6).Tahap evaluasi. 7).Tahap terminasi. 


\section{Pandangan Islam tentang Pemberdayaan}

Pemberdayaan umat merupakan salah satu bentuk hubungan yang terjadi antar sesama manusia atau bagian integral muamalah. Dengan muamalah akan tercipta suatu masyarakat yang saling membantu (Daulay, 2016). Masyarakat yang memiliki kemampuan bila membantu yang kurang mampu maka hal ini dapat mewujudkan dan menciptakan masyarakat mandiri terutama di bidang sosial dan ekonomi. Allah berfirman dalam Q.S. al-Hajj ayat 41 :

"Mereka jika Kami beri tempat (kekuasaan) di muka bumi, mereka mendirikan sembahyang dan membayarkan zakat serta menyuruh dengan makruf (kebaikan) dan melarang yang mungkar (kejahatan). Dan kepada Allah (terserah) akibat semua pekerjaan."

Pemberdayaan masyarakat khususnya bagi keluarga Muslim adalah konsep yang sangat penting terutama karena memberikan perspektif positif terhadap orang muslim yang miskin. Islam menganggap kemiskinan sebagai keadaan yang tidak selaras dengan martabat manusia sebagai khalifatullah. Oleh sebab itu setiap manusia sehat yang secara fisik dan mental, diharuskan untuk menopang dirinya dan keluarganya. Hal ini tidak mungkin terwujudkan kecuali apabila tersedia fasilitas untuk melatih mereka menjadi produktif melalui pemberdayaan kemampuannya dan juga diberikan kesempatan untuk berwirausaha dan bekerja untuk mendapatkan gaji. Pada akhirnya terjadi pemerataan pendapatan dan kesejahteraan sosial ekonomi.

\section{METODE}

Penelitian ini merupakan penelitian kualitatif. Arikunto (2002) menerangkan bahwa kualitatif menunjukkan penelitian yang terjadi apa adanya dalam situasi yang tidak dimanipulasi keadaan serta kondisinya. Pendekatan penelitian ini adalah participatory action research, yang berguna untuk diterapkan pada pemberdayaan masyarakat maupun kelompok dengan langsung berinteraksi dan bersosialisasi, sehingga akan meningkatkan capacity building dan self confident dari masyarakat. Jenis penelitian ini merupakan penelitian deskriptif analitik. Menurut Sugiyono (2008) penelitian deskriptif analitik didefinisikan sebagai penelitian yang dilakukan dengan cara mengumpulkan data dan informasi sesuai dengan kondisi yang sebenarnya, kemudian data-data tersebut disusun, diolah dan dianalisis untuk dapat memberikan gambaran mengenai peran-peran apa 
saja yang ditemukan, yang berkaitan dengan peran institusi masjid sebagai pusat pemberdayaan sosial ekonomi masyarakat, studi di Masjid Sabilillah Malang.

Unit analisis dalam penelitian ini adalah peran institusi masjid. Sebagai sebuah institusi yang memiliki peran yang sangat luas, maka penelitian ini difokuskan pada berbagai program, aktivitas, dan kegiatankegiatan yang telah dilakukan dalam memberdayakan masyarakat, khususnya dalam bidang sosial ekonomi.

Metode pengambilan informan yang digunakan adalah Non Probability Sampling (Indriantoro dan Supomo, 2002). Adapun kriteriakriteria informan yang ditentukan dalam penelitian ini yaitu yang memiliki wawasan serta pengetahuan mengenai topik peran institusi masjid yang diteliti. Informan masih atau sedang terlibat dalam kegiatan dan programprogram di Masjid Sabilillah yang tengah diteliti, sehingga up to date terhadap masalah-masalah baru dan perkembangan program, terutama dibidang pemberdayaan sosial ekonomi masyarakat. Adapun informan penelitian ini adalah pengurus Masjid Sabilillah, yang terdiri dari Pimpinan Yayasan, dan berbagai pengurus yang menjadi penanggung jawab programprogram pemberdayaan yang diselenggarakan di Masjid Sabilillah. Dan juga masyarakat yang diberikan bantuan dan mengakses modal usaha kepada LAZIS dan Koperasi Masjid Sabilillah.

Wawancara dilakukan secara terbuka dan tidak terstruktur ketat. Observasi dilakukan secara langsung pada awal peninjauan lokasi dan penentuan informan di Masjid Sabilillah.

Interpretasi data dalam penelitian ini didasarkan pada tahapan model alir, sebagaimana yang telah disampaikan oleh Miles dan Huberman (1992). Yaitu pengumpulan data, reduksi data, dan penyajian serta verifikasi data berjalan secara simultan. 


\section{PEMBAHASAN}

\section{Pemberdayaan Sosial Masyarakat di Masjid Sabilillah}

\section{Pembinaan Kepada Keluarga Mustahik oleh LAZIS Sabilillah}

Sejak tahun 2008 terdapat agenda pertemuan rutin setiap bulan, yakni pada tanggal 10 diselenggarakan santunan sekaligus pembinaan untuk keluarga dhuafa, baik anak-anak maupun orang tua. Sampai dengan tahun 2016 tercatat sejumlah 150 anggota keluarga binaan LAZIS Sabilillah. Keseluruhan keluarga ini mendapatkan bantuan pendidikan dan pembinaan. Pelaksanaan program pertemuan rutin ini mempunyai manfaat besar, diantaranya adalah pembekalan tentang agama, akhlak dan juga pembinaan lainnya. Sebagaimana yang dikemukakan beberapa keluarga berikut ini :

Bu Rusti : "Alhamdulillah ya disini itu bisa ngaji, kadang-kadang juga di tuturi. Saya sudah bersyukur".

Bu Nurul : "Disini ya pengajian, anak saya juga ngaji, juga disuruh nabung setiap pertemuan".

\section{Pengembangan dan Peningkatan Kualitas Pendidikan}

LAZIS Sabilillah memberikan bantuan biaya pendidikan dan uang bulanan kepada anggota binaan. Sebagai timbal balik, pihak LAZIS Sabilillah akan meminta laporan hasil belajar dari sekolah dan mengevaluasi hasil belajar siswa di setiap waktu kenaikan kelas. Banyak dari kaum dhuafa yang memiliki putra-putri yang tidak memiliki kemampuan, ditanggung biayanya oleh LAZIS Sabilillah. Bahkan, ada beberapa anak binaan yang merupakan anak yang berprestasi. Selain itu ada pula anak binaan lainnya yang sampai melanjutkan ke jenjang S2 di UGM, semua mendapatkan biaya dari LAZIS Sabilillah.

Selain itu terdapat program peningkatan minat baca khususnya bagi anak-anak yatim dan dhuafa serta santri TPQ mengunjungi perpustakaan Masjid Sabilillah. Namun kegiatan yang potensial ini telah lama tidak dilaksanakan kembali, karena adanya focus kepada program lain.

\section{Pendampingan Penyelesaian Permasalahan Keluarga Binaan}

Masjid Sabilillah melalui LAZIS Sabilillah, memiliki layanan pendampingan kepada masyarakat khususnya bagi keluarga binaannya. Seperti dalam mengatasi jeratan hutang dengan bank thitil. Selain itu juga memberikan edukasi kepada masyarakat tentang dampaknya berhutang kepada rentenir. Kemudian LAZIS Sabilillah juga menumbuhkan semangat 
untuk bangkit dengan memulai usaha baru kepada mereka yang terlitit hutang. Selain itu dalam permasalahan keluarga lainnya, LAZIS Sabilillah juga turut menjadi tempat konsultasi bagi anggota binaan.

\section{Pelatihan Usaha Anggota Binaan}

LAZIS dan Koperasi Sabilillah memiliki banyak anggota dan mustahik yang mempunyai usaha-usaha kecil dan menengah seperti halnya usaha gorengan, bakso, abon lele, abon bandeng, bandeng presto, juga berbagai ragam oleh-oleh khas malang, hingga jenis usaha tanaman hidroponik. Para pelaku usaha ini dihimpun menjadi anggota koperasi dan akan diberikan bermacam pelatihan untuk mengembangkan usaha mereka.Adapun tujuan program ini adalah untuk kesejahteran umat, sebagaimana diungkapkan oleh Manajer LAZIS Sabilillah :

"Ibadahnya bertambah khusyuk karena dagangannya lancar, usahanya berkah serta ilmunya bermanfaat. Ini merupakan kerja dakwah LAZIS Sabilillah dalam memberdayakan umat untuk menjadi umat yang terampil, berdaya saing dan berintegritas dalam menghadapi persaingan usaha. Maka dari kerja-kerja dakwah tersebut".

Salah satu upaya untuk meningkatkan nilai tambah yaitu nilai jual produk, memperluas akses pemasaran/jaringan dan akan menambah kepercayaan konsumen terhadap suatu produk adalah pembinaan creative skill seperti pada gambar berikut :

\section{Gambar 1. Membuat Kemasan Produk}

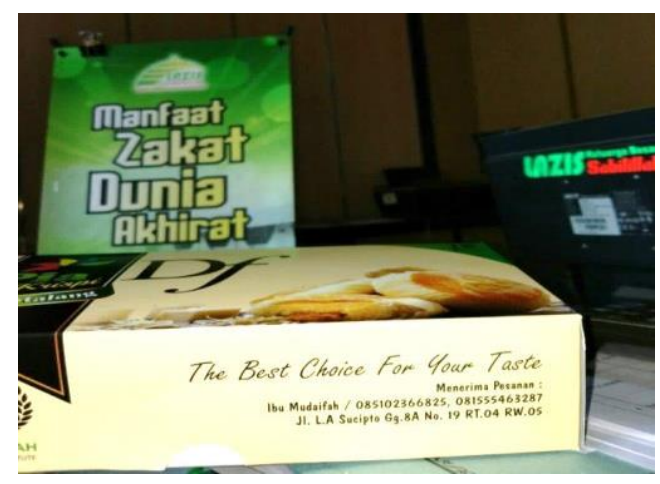

Sumber : Dokumentasi Penulis, 2017 
Namun kegiatan ini lambat laun mengalami penurunan intensitas pelaksanaannya. Hingga tahun 2017 kegiatan pelatihan tidak terlaksana akibat terkosentrasi pada kegiatan program-program lainnya. terlebih lagi kurangnya komunikasi antara pengurus serta koordinasi yang kurang menyebabkan kegiatan yang sangat potensial ini mengalami kemunduran.

\section{Menumbuhkan Kesadaran Masyarakat akan Pentingnya Kesehatan}

Di Masjid Sabillah terdapat sebuah klinik yang bernama Sabilillah Medical Service (SMS). Beberapa tujuan berdirinya klinik ini adalah salah satunya untuk pemberdayaan masyarakat di bidang kesehatan. Bagaimana masyarakat mampu menghadapi masalah-masalah potensial (yang mengancam) dengan cara mencegahnya dan mengatasi masalah-masalah kesehatan yang sudah terjadi dengan menanganinya secara efektif dan efisien. Selain itu Pengurus SMS juga mengedukasi masyarakat untuk memiliki kesadaran akan pentingnya kesehatan. Hingga Juni 2017 tercatat sebanyak 986 orang yang menjadi anggota BPJS di Masjid Sabilillah.

\section{Pemberdayaan dan Penguatan Jaringan dengan Mushollah Binaan}

Program pemberdayaan musholla berikut pula takmirnya, bertujuan agar musholla-musholla tersebut nantinya dapat memberdayakan masyarakat di sekitarnya. Masjid Sabilillah mentransfer pengetahuan dan kemampuan yang dimiliki kepada masjid atau musholla lain. Tujuannya untuk mempelajari berbagai pengetahuan, seperti diantaranya pengelolaan manajemen masjid, keuangan, peningkatan jama'ah, perawatan bangunan dan lingkungan masjid, serta keaktifan pengurus. Hasilnya banyak musholla berdaya dan mandiri, beberapa takmir musholla juga dibina untuk memiliki unit bisnis seperti persewaan tenda, hingga kini musholla-musholla tersebut dapat memenuhi kebutuhan operasional musholla mereka sendiri tanpa mengandalkan sumbangan semata.

\section{Memberdayakan Ekonomi Masyarakat Melalui Koperasi Masjid Sabilillah}

\section{Pemberdayaan Karyawan}

Di Masjid Sabilillah sebagai masjid besar yang memiliki banyak karyawan, maka perhatian juga ditunjukkan dengan memperhatikan kesejahteraan perangkat masjid atau karyawan yang selama ini seringkali kurang diperhatikan seperti para imam sholat, muadzin, guru mengaji, karyawan Sabilillah lainnya yang dipikirkan, ditanggung dan berupaya disejahterakan di Masjid Sabilillah. Mereka juga turut serta aktif dan 
berpartisipasi dalam setiap kegiatan dan yang diselenggarakan oleh Masjid Sabilillah. Di koperasi masjid mereka merupakan anggota dan memiliki tabungan, dan juga sebagai karyawan, mereka mendapatkan kemudahan untuk meminjam. Hal ini sejalan apa yang dikemukakan Alma (2002) bahwa partispasi akan memunculkan kesadaran anggota dalam menabung dan menghimpun dana yang akan disalurkan kepada anggota lainnya.

\section{Pemberdayaan Ekonomi Kaum Dhuafa Melalui Modal Usaha dan Sarana Produksi}

Tingkat ekonomi dari masyarakat binaan LAZIS Sabilillah yang terdiri dari kaum dhuafa dan fakir miskin ini secara ekonomi terjadi peningkatan pendapatan. Meskipun belum terlalu drastis, tetapi cukup membantu masyarakat mengatasi kesulitan ekonominya. Berikut ini disajikan beberapa anggota binaan LAZIS Sabilillah yang mendapatkan bantuan modal usaha:

1. Bu Liana seorang asisten rumah tangga. Untuk menambah pendapatannya, ia mulai menjual keripik singkong yang didistribusikan langsung di warung-warung. Modal sendiri sebesarRp. 250.000, kemudian melalui LAZIS Sabilllah Hingga kini perkembangan usahanya kian pesat. Ia juga rajin melaporkan perkembangan usahanya.

2. Pak Sukriono penjual es doger mendapatkan modal usaha sebesar Rp.1.000.000. Usahanya kian berkembang dan pendapatan perharipun meningkat dibandingkan sebelum mendapat modal. Selain itu Pak Sukri dan anaknya aktif mengikuti pembinaan.

3. Bu Jumiati merupakan anggota binaan baru di LAZIS Sabilillah. Pada tahun 2016, ia memiliki banyak hutang kepada rentenir. Sebagai upaya pemberdaayaan ekonomi, ia mendapatkan modal usaha sebesarRp. 500.000 serta gerobak untuk berjualan gorengan dan kue basah. Hingga kini usahanya berkembang dan $\mathrm{Bu}$ Jumiati dapat melunasi hutangnya kepada rentenir. 


\section{Gambar 2. Bantuan Modal Usaha dan Gerobak Untuk Bu Jumiati}

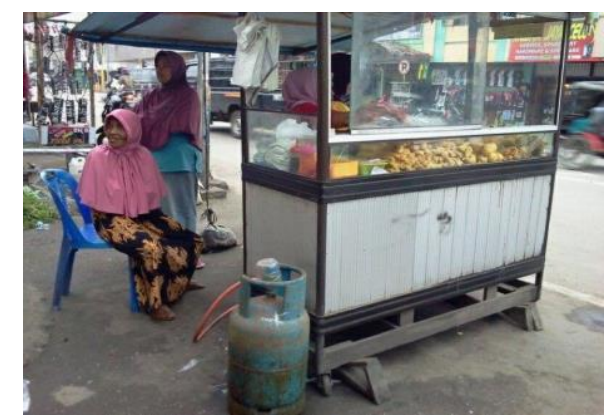

Sumber :Dokumentasi LAZIS, 2016

Dari beberapa pemaparan diatas, terdapat beberapa upaya-upaya masyarakat untuk berkembang melalui terkait dengan kemampuan berwirausaha dari masyarakat, yang dilaksanakan menghasilkan 1) memberikan wawasan, sikap, dan keterampilan usaha, 2) memberikan peluang, 3) memfasilitasi (modal pinjamaan), dan 4) memonitor dan mengevaluasi bagaimana perkembangan usahanya. Hal ini sesuai dengan yang dijelaskan Sulistiyani (2004) bahwa tujuan yang ingin dicapai dari pemberdayaan masyarakat adalah untuk membentuk individu dan masyarakat memiliki kemandirian ekonomi.

\section{Pemberdayaan Ekonomi Melalui Penyediaan Pasar Pujasera}

Berdirinya Pujasera Sabilillah ditujukan untuk pengembangan Usaha Kecil Menengah (UKM), dengan menyediakan dan memfasilitasi tempat bagi mereka. Kegiatan pokok yang dilaksanakan melalui program pujasera, yaitu dengan memfasilitasi usaha-usaha kecil untuk dapat berdagang dan berjualan di lingkungan Masjid Sabililllah.

Di Pujasera lama terdapat beberapa pedagang diantaranya adalah Cak Budi penjual bakso, Bu Salwa penjual jamur krispi dan penjual yogurt. Berdasarkan keterangan informan, bahwasannya disaat pujasera pertama berdiri tahun 2012, beberapa penjual merasakan manfaat dengan memperoleh penghasilan yang mencukupi. Hal ini karena banyak pembeli dari berbagai kalangan, seperti jamaah masjid, karyawan masjid, guru-guru, serta karyawan di seputar area Masjid Sabilillah.

Namun sejak ada peraturan baru, terjadi perpindahan pedagangpedagang kecil tersebut. Beberapa diantaranya keberatan dengan sistem 
pujasera yang baru dikerenakan setiap minggunya pendapatan penjual dipotong sebesar $20 \%$. Sebagaimana diungkapkan penjual yogurt :

"ya kita keberatan mbak, kalau segitu 20\% perminggu ya kita ga mampu, makanya kita pindah."

Proses perencanaan program sebagaimana tersebut di atas memiliki banyak kelemahan. Pertama, adanya keberpihakan pada kepentingan elit dari pada kepentingan masyarakat miskin (Tjokrowinoto, 2002). Kedua, partisipasi yang dijalankan oleh masyarakat miskin merupakan partisipasi semu, karena mereka berpartisipasi secara terpaksa dan dipaksa (Mikkelsen, 2003). Ketiga, peran fasilitator tidak nampak, padahal fasilitator seharusnya siap sedia membantu masyarakat dalam menganalisis permasalahan dan memecahkan masalah yang dihadapi (Mardikanto, 2010).

\section{Aktivitas Masjid yang Menghasilkan Sumber Dana Lain Untuk Pemberdayaan Sosial Ekonomi Masyarakat}

\section{Penyewaan Auditorium}

Di Masjid Sabilillah penggunaan gedung dimanfaatkan dengan cara disewakan kepada masyarakat. Adapun pendapatan dari biaya persewaan gedung tersebut dipergunakan untuk perawatan masjid serta untuk gaji para karyawan. Sehingga ada upaya diantara sesama pengurus untuk mengatasi kebutuhan harian dan saling membantu mereka dengan memaksimalkan fungsi masjid untuk membangun kekuatan ekonomi yang memanfaatkan segala potensi yang dimiliki oleh masjid, baik itu potensi jamaah, potensi lokasi masjid, potensi ekonomi masyarakat sekitar masjid, dan potensipotensi lainnya. Bila kesemua potensi tersebut dapat dikelola dengan baik, maka problematika pengangguran dan kemiskinan, yang menjadi musuh utama umat Islam dewasa ini, akan dapat diminimalisasi (Dalmeri, 2014).

\section{Wakaf Uang Tunai}

Dana wakaf tunai diprogramkan dan dihimpun oleh Koperasi Masjid Sabilillah sejak tahun 2003 hingga tahun 2016. Hingga tahun 2016 jumlah wakaf uang tunai yang terhimpun di Koperasi Masjid Sabilillah sebesar Rp.947.178.000. Sistem pengelolaan wakaf uang yang ada di Masjid Sabilillah menggunakan sistem simpan pinjam seperti dalam koperasi, namun dikelola secara syariah. Untuk pengumpulan dana wakaf tersebut, para pengurus koperasi telah memberlakukan prosedur perkoperasian. Yakni setiap orang yang hendak melaksanakan wakaf uang harus terlebih dahulu menjadi anggota Koperasi Masjid Sabillah. 
Hal ini merupakan upaya optimalisasi masjid menjadi sentral dakwah dan pemberdayaan umat, seperti yang dijelaskan oleh Manajer Koperasi Masjid Sabilillah:

"Wakaf yang dikelola oleh KOPMAS bertujuan yang pertama untuk mensejaterakan umat, kedua untuk mengurangi kemiskinan umat, ketiga mmbentuk jaringan dan memberdayakan umat. Bagaimana UKM nya disejahterakan, karyawan, tukang becak, pedagang kaki lima guru dan sebagainya".

Alokasi pemanfaatan wakaf diperuntukkan bagi internal maupun eksternal Masjid Sabilillah. Melalui wakaf diharapkan akan terjadi proses distribusi manfaat bagi masyarakat secara lebih luas, dari manfaat pribadi (private benefit) menuju manfaat masyarakat (social benefit).

\section{Kerjasama Pengelolaan Mini Market}

Kerjasama ini dilakukan antara Yayasan Sabilillah dan Badan Wakaf. Dengan kesepakatan bahwa lahan dan bangunan mini market adalah milik Yayasan Sabilillah, sedangkan produk-produk mini market dan pendanaannya berasal dari Badan Wakaf. Berdasarkan pengelolannya, terdapat aturan main yang berlaku setelah Break Even Point (BEP). Diantaranya adalah sebagai maukuf alaih (yang menerima wakaf) dalam hal ini Masjid Sabilillah diwajibkan untuk melaporkan penyaluran hasil keuntungan yang ditujukan untuk insentif bisyarah (upah) kepada imam rawatib. Harapan mini market yang dimiliki Masjid Sabilillah ini memiliki jaringan yang seperti halnya alfamart ataupun indomart dengan basic berangkatnya dari masjid ke masjid atau dari mushola ke mushola.

\section{KESIMPULAN}

Berdasarkan hasil penelitian yang telah dipaparkan, maka dapat ditarik kesimpulan sebagai berikut : a).Masjid Sabilillah menghidupkan berbagai fungsi masjid, seperti peribadahan, social pendidikan, kesehatan, dan ekonomi. Masjid Sabilillah memiliki kelengkapan fasilitas yang menunjang peran masjid, diantaranya seperti klinik kesehatan, auditorium, koperasi masjid, kantin pujasera, LAZIS dan perpustakaan masjid. b). Keberadaan pengurus Masjid Sabilillah sebagai fasilitator sekaligus pendidik dan pendamping membawa manfaat besar bagi masyarakat. Banyak masyarakat yang terbantu seperti kaum dhuafa, masyarakat pengangguran, 
hingga para pengusaha yang telah terbantu baik dari program social maupun ekonominya.

Pemberdayaan sosial masyarakat di Masjid Sabilillah dilaksanakan dengan: a).Kegiatan pembinaan pada keluarga kaum dhuafa dalam pertemuan rutin yang diisi dengan pengajian, konsultasi dan motivasi. Hasilnya banyak anggota binaan senang mendapatkan arahan dan ilmu dari kegiatan ini. b).Untuk anak-anak yatim LAZIS Sabilillah, dilakukan pendampingan dan bantuan pendidikan,banyak anak binaan Sabilillah yang berprestasi dan menjadi anak binaan lebih dari enam tahun dan hingga dapat lulus sampai dengan SMA. c).Pendampingan berbagai persoalan keluarga. Hasilnya banyak masyarakat terbantu baik secara finansial maupun psikologis. d).Pelatihan untuk pengusaha binaan, namun kegiatan ini telah lama belum dilaksanakan kembali. e).Mengembangkan modal sosial melalui pembinaan takmir musholla yang profesional. Hasilnya banyak musholla berdaya dan mandiri, memiliki unit bisnis dan tidak hanya mengandalkan infak semata. f). meningkatkan kesadaran pentingya kesehatan. Hasilnya banyak masyarakat yang mendaftarkan diri pada BPJS Masjid Sabilillah. Terlebih adanya edukasi yang di sampaikan setiap bulan.

Pemberdayaan ekonomi masyarakat di Masjid Sabilillah dilaksanakan dengan: a).pinjaman modal untuk pengusaha binaan. Hasilnya menunjukkan bahwa pendapatan sebelum dan sesudah mendapatkan dana pinjaman, ditemukan bahwa omset penjualan rata-rata per bulan anggota mengalami peningkatan. b).Memberikan kemudahan syarat dan agunan untuk mendapatkan pinjaman modal di Koperasi Masjid Sabilillah, hanya dengan KTP, surat nikah dan akta kelahiran anak. Hal ini membuat semua golongan masyarakat, terlebih masyarakat kecil dapat dengan mudah memperoleh pinjaman baik untuk konsumtif maupun produktif.

\section{DAFTAR PUSTAKA}

Adi, IR. 2003. Pemberdayaan Pengembangan Masyarakat dan Intervensi Komunitas: Pengantar Pada Pemikiran dan Pendekatan Praktis. Jakarta: Lembaga Penerbit Fakultas Ekonomi UI.

Alma. Buchari 2002. Manajemen Pemasaran dan Pemasaran Jasa. Bandung : CV. Alfabeta.

Arikunto, Suharsimi. 2002. Metodologi Penelitian. Penerbit PT. Rineka Cipta. Jakarta. 
Chaidir, Achmad. 2009. Strategi peningkatan Peran Lembaga Kemasyarakatan Dalam Penanggulangan Kemiskinan di Kota Pekanbaru. Laporan akhir Penelitian Insidental. Riau : Universitas Riau.

Dalmeri. 2014. Revitalisasi Fungsi Masjid sebagai Pusat Ekonomi dan Dakwah. Jurnal Walisongo, Volume 22, Nomor 2, November 2014.

Daulay, Raihanah. 2016. Pengembangan Usaha Mikro Untuk Pemberdayaan Ekonomi Umat di Kota Medan. Jurnal Miqot Vol. XL No. 1 Januari-Juni 2016.

Friedmann, John. 1992. Empowerment, The Politics of Alternative Development. Cambridge Mass: ISBN: 978-1-55786-300-3. WileyBlackwell publisher.

Indriantoro, Nur dan Bambang Supomo. 2002. Metodologi Penelitian Bisnis Untuk Akuntansi Dan Manajemen. Edisi Pertama. BPFE,Yogyakarta.

Mardikanto, 2010. Konsep Pemberdayaan Masyarakat, Penerbit TS, Surakarta.

Miles, Matthew B. dan Huberman, A. Michael. 1992. Analisis Data Kualitatif. Universitas Indonesia, Jakarta.

Mikkelsen Britha. 2003. Metode Penelitian Partisipatoris dan Upaya-Upaya Pemberdayaan: Sebuah Buku Pegangan Bagi Para Praktisi Lapangan. Jakarta: Yayasan Obor Indonesia.

Sugiyono. 2008. Metode Penelitian Kuantitatif, Kualitatif dan $R \&$ D. Bandung : Alfabeta.

Sulistyani, Ambar Teguh 2004, Kemitraan dan Model-Model Pemberdayaan. Yogyakarta : Graha Ilmu.

Sutoro, Eko. 2002. Pemberdayaan Masyarakat Desa, Materi Diklat Pemberdayaan Masyarakat Desa, yang diselenggarakan Badan Diklat Provinsi Kaltim, Samarinda, Desember 2002.

Tjokrowinoto, M. 2002. Kopi Kajian Ekonomi Sosial. Kanisius. Yogyakarta 